\title{
Gram per Gram per Day
}

National Cancer Institute

\section{Source}

National Cancer Institute. Gram per Gram per Day. NCI Thesaurus. Code C73720.

A dose calculation unit expressed in gram(s) per gram per period of time equal to twentyfour hours. 